\title{
Der Entwurf
}

des

\section{Russischen Zivilgesetzbuches}

Dargestellt und besprochen

von

Wilhelm von Seeler

Professor an der Universität Berlin

Berlin 1911.

J. Guttentag, Verlagsbuchhandlung,

G. m. b. H. 
Alle Rechte vorbehalten, auch das Recht der Obersetzung ins Russische gemäß dem russischen Gesetze vom 20. März 1911, Art.33.

Der Verfasser. 